\title{
Body Fat and Somatotype among Malaysian School Netball Players by Playing Performance 依據比賽表現探索馬來西严體育學校理事會 投球球員的體脂和體型
}

K. G. SOH $^{1}$ K. L. SOH ${ }^{2}$ MOHD. SOFIAN, O. F. ${ }^{1}$

S. L. $\mathrm{ONG}^{3} \quad$ NOORZALIZA, $\mathrm{O}^{4}$

${ }^{1}$ Sports Studies Department, Faculty of Educational Studies, University Putra Malaysia, MALAYSIA

${ }^{2}$ Department of Community Health, Faculty of Medicine and Health Sciences, University Putra Malaysia, MALAYSIA

${ }^{3}$ Nursing Department, Faculty of Medicine and Health Sciences, Universiti Darul Iman Malaysia, MALAYSIA

${ }^{4}$ Department of Sports Psychology \& Coaching Science, Faculty of Sports Science, Educational University of Sultan Idris, MALAYSIA

蘇金玉 ${ }^{1} \quad{\text { 蘇金蘭 }{ }^{2} \text { 莫哈末蘇菲安 }}^{1}$

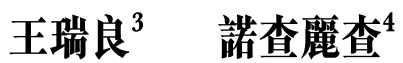

${ }^{1}$ 馬來西亞博特拉大學教育研究院運動學系

${ }^{2}$ 馬來西亞博特拉大學醫學和健康科學院社會學系

${ }^{3}$ 馬來西亞拉咯伊曼大學醫學和健康科學院護理系

${ }^{4}$ 馬來西亞蘇丹伊利斯大學運動科學院運動心理和科學訓練系

\begin{abstract}
This research was to determine the anthropometric profile among Under-18 year old Malaysian School Sports Council (MSSM) netball players. The anthropometric measures taken were height, body mass, body fat, and somatotype. It also investigated the differences in the anthropometric profile by playing performance. The subjects were all the 150 netball players who represented their states in the Under-18 MSSM Netball Competition in 2006. They were divided into three categories by their playing performance - good, medium and fair. The body fat was measured using the skinfold method, and the somatotype using the Heath and Carter Somatotyping method. A significant difference was found in height by playing performance, with $f$-value of $f(2,147)=4.82$, $(p<.01)$. However, there were no significat differences in body mass, body fat and somatotype. The mean parameter values were height $(164.79 \pm 6.40 \mathrm{~cm})$, body mass $(58.76 \pm 9.22 \mathrm{~kg})$, body fat $(12.23 \pm 3.49 \%)$ and somatotype $(3.29 \pm 0.99-3.52 \pm 1.48-2.69 \pm 1.18)$. The best players were the tallest, heaviest and had the highest body fat. They also had meso-endomorphic bodies while the lesser players were endo-mesomorphic.
\end{abstract}




\section{摘 要}

此研究是測定馬來西亞體育學校理事會18歲以下投球球員的外型人體測量。人體浿量度是以球員的高度、體質量、體脂和體 型分類來判斷。藉此從表現狀況調查外型人體測量的差別。150名受試者都是代表各州參加2006年18歲以下馬來西亞體育學校理事 會投球賽的球員, 把她們的比賽表現分為三組 - 優良、中等和一般。研究運用測量皮膚表層的方法來固定體脂與Health-Carter 人體測量方法測定體型調查。依據比賽的表現, 發現球員的高度有顯著的差別 $f(2, \quad 147)=4.82, \quad(p<.01) \circ$ 可是, 體質量、體脂 和 體型分類卻没有明顯的差異。調查結果顯示各平均參數如下: 高度 $(164.79 \pm 6.40 \mathrm{~cm})$, 體質量 $(58.76 \pm 9.22 \mathrm{~kg})$, 體脂 $(12.23 \pm 3.49 \%)$ 和體型分類 $(3.29 \pm 0.99-3.52 \pm 1.48-2.69 \pm 1.18) \circ$ 最優秀的球員身材較高大, 擁有較高的體脂, 她們多具有中胚層-內 肧層體型而少數的球員是屬內胚層-中肧層體型。

\section{Introduction}

Netball is one of most popular contact games for women in Malaysia. The game evolved from a common progenitor with basketball, and therefore there are similarities between the games. The netball game is so well accepted among Malaysian women because it is easy to play and does not need a large area to play as compare to football or hockey. However, netball court is slightly larger than basketball court. Moreover, it is not an expensive sport. It is therefore not surprising that the game has experienced tremendous growth in the country and is played either as competitively sport as well as socially.

Netball is played by two opposing teams and each team consists of seven players. Two unique things about the netball game as compared to the basketball game are: Players' movements are limited to their specific playing positions and the players are not allowed to run with the ball and take more than one and a half steps after receiving the ball. The objective of the game is to score as many goals as possible against the opponent by putting the ball through their net. The winner is the scorer of the most goals. Likewise basketball, the netball game also involves a lot of running, dashing about and jumping. The netball game also requires specific skills such as passing and catching the ball. Hence, to be a good player would not only require mastery of certain skills, but also the posession of certain physical attributes. According to the Malaysian Netball Association, height and a certain body type, or somatoype, are among the major requirements to excel in the game. Since netball is usually played by youths, especially students, this research was conducted to determine the anthropometric profile of Under-18 Malaysian School Sports Council (MSSM) players and investigate their differences by playing performance.

\section{Method and Procedures}

\section{Subjects}

One hundred and fifty players from 15 netball teams were studied - representing all the 13 states and 2 Federal Territories of the country in the MSSM 2006 Under-18 games. Their mean age was $16.75 \pm 0.72$, from a range of 13 to 18 years old. They were divided into three categories by their playing performance - good, medium and fair. The categorization of a player was based on her team performance in the tournament. The 'good' players were from the teams coming out 1 st to 5 th in the tournament, 'medium' players from the teams ranked 6-10, and 'fair' players from teams 11-15. The numbers of players in each category are shown in Table 1 .

Table 1. Grouping of Netball Players by Thier Playing Performance

\begin{tabular}{cccc}
\hline \multicolumn{3}{c}{ Player Performance Category } & Total \\
\hline Good & Medium & Fair & \\
50 & 50 & 50 & 150 \\
\hline
\end{tabular}




\section{Measurement Protocol}

This work was done at Juara Stadium, Bukit Kiara, Kuala Lumpur. Height and body mass were measured using the Moveable Anthropometre Portable Height Ruler and Tanita 2000 Weighing Scale, respectively. The skinfold measurement was used to determine the body fat content as it has been found suitable for more muscular people like athletes (Adam, 1994). Besides, the results from the method (mean from four sites) are well-correlated ( $\mathrm{r}$ $=0.84$ ) with laboratory hydrostatic weighing (Telford et al., 1985, 1980; Adams, 1994). The four selected sites were the triceps, anterior thigh, suprailliac area and abdomen. The calculation of body fat percentage was based on the formula by Jackson et al. (1980).

The Heath and Carter method was used to determine the body type from the measurements of height, body mass, skinfold thickness (scapular and calf), biceps and calf girths, and humerus and femur widths. The skinfold measurements were taken starting from the right side of the body, then slowly rotating around the body to avoid putting too much pressure on any spot by pinching it (Lohman et al., 1991). Trained personnel took all the measurements to minimize inter-tester error (Tothill \& Stewart, 2002; Marfell et al., 2006). Two readings were first taken for each side and rounded up to the nearest $\mathrm{mm}$ or $\mathrm{cm}$. Only if the two readings were within one $\mathrm{mm}$ or $\mathrm{cm}$ of each other were they accepted. When not, a third measurement was taken and the two closest readings within the error range accepted.

\section{Statistical Analysis}

The body fat and somatotype differences between playing positions were identified using one-way ANOVA. If the difference was significant, a post hoc analysis using the Scheffe test was carried out to investigate the nature of the difference (Nie et al., 1975; Pallant, 2001).

\section{Results}

There was a significant difference in height between the playing performance with the good players taller than the fair ones. The mean difference was $3.85 \mathrm{~cm}$. No significant differences were found for body mass, body fat and somatotype. The overall parameter means were height $(164.79 \pm 6.40 \mathrm{~cm})$, body mass $(58.76 \pm 9.22 \mathrm{~kg})$, body fat $(58.76 \pm 9.22 \mathrm{~kg})$ and somatotype (3.29-3.52-2.69) (Table 2).

The good players were the tallest, heaviest and had the highest body fat. They also had meso-endomorphic bodies while the lesser players were more endomesomorphic. The somatotypes were: good players $3.44+0.99$ - 3.42+1.55 - 2.84+1.13, medium players 3.29+1.00 - 3.35+1.34 - $2.75+1.23$ and fair players $3.13+0.98-3.81+1.54-2.49+1.17$.

Table 2. Anthropometric Profiles of Players by Playing Performance.

\begin{tabular}{|c|c|c|c|c|c|c|}
\hline \multirow{2}{*}{$\begin{array}{l}\text { Playing } \\
\text { Performance }\end{array}$} & \multirow{2}{*}{$\begin{array}{l}\text { Height } \\
(\mathrm{cm})\end{array}$} & \multirow{2}{*}{$\begin{array}{l}\text { Body } \\
\text { Mass } \\
(\mathrm{kg})\end{array}$} & \multirow{2}{*}{$\begin{array}{l}\text { Body } \\
\text { fat } \\
(\%)\end{array}$} & \multicolumn{3}{|l|}{ Body Type } \\
\hline & & & & Endomorphic & Mesomorphic & Ectomorphic \\
\hline Good & 166.82 & 60.16 & 12.92 & 3.44 & 3.42 & 2.84 \\
\hline $\begin{array}{l}\text { SD } \\
\text { Medium }\end{array}$ & $\begin{array}{l}6.10 \\
164.49\end{array}$ & $\begin{array}{l}7.95 \\
57.78\end{array}$ & $\begin{array}{l}3.87 \\
12.10\end{array}$ & $\begin{array}{l}0.99 \\
3.29\end{array}$ & $\begin{array}{l}1.55 \\
3.35\end{array}$ & $\begin{array}{l}1.13 \\
2.75\end{array}$ \\
\hline $\begin{array}{l}\text { SD } \\
\text { Fair }\end{array}$ & $\begin{array}{l}6.11 \\
162.97\end{array}$ & $\begin{array}{l}8.59 \\
58.34\end{array}$ & $\begin{array}{l}3.44 \\
11.66\end{array}$ & $\begin{array}{l}1.00 \\
3.13\end{array}$ & $\begin{array}{l}1.34 \\
3.81\end{array}$ & $\begin{array}{l}1.23 \\
2.49\end{array}$ \\
\hline $\begin{array}{l}\text { SD } \\
\text { Mean }\end{array}$ & $\begin{array}{l}6.49 \\
164.79\end{array}$ & $\begin{array}{l}10.87 \\
58.76\end{array}$ & $\begin{array}{l}3.07 \\
12.23\end{array}$ & $\begin{array}{l}0.98 \\
3.29\end{array}$ & $\begin{array}{l}1.54 \\
3.52\end{array}$ & $\begin{array}{l}1.17 \\
2.69\end{array}$ \\
\hline SD & 6.40 & 9.92 & 3.49 & 0.99 & 1.48 & 1.18 \\
\hline \multirow[t]{2}{*}{ Significant } & $\mathrm{F}=4.82$ & $\mathrm{~F}=0.91$ & $\mathrm{~F}=1.68$ & $\mathrm{~F}=1.20$ & $\mathrm{~F}=1.36$ & $\mathrm{~F}=1.21$ \\
\hline & $\mathrm{P}<.01$ & $\mathrm{p}<.41$ & $\mathrm{p}>.19$ & $\mathrm{p}>.30$ & $p>.26$ & $\mathrm{p}>.30$ \\
\hline
\end{tabular}




\section{Discussion}

The mean height of the players was $164.79+$ $6.40 \mathrm{~cm}$. The good players were the tallest, followed by the medium and then fair players. Taller players are advantaged in shooting, rebounding and defending. Hence, the better players can be expected to be taller than the lesser ones (Soh et al., 2007). Similar results were reported by Soh (2005) and Soh et al. (2006) with elite/senior Malaysian netball players being taller than the players in the lesser categories. However, the difference in these studies was not significant, possibly be due to the small gap between the players as all of them could be considered good, already representing the country whether in the Under-21, Under-19 and Under-17 age categories.

The good players were also the heaviest and had the highest body fat. However, even they lost out to the elite Malaysian players who were yet heavier and with even more body fat (Soh, 2005; Soh et al., 2006). Similar results (higher body mass and body fat) were reported in other studies in Australia and England (Hopper et al., 1995; Bale \& Hunt, 1986). As the rule, higher body mass and body fat were possessed by better netball players than the MSSM players in this research (Soh, 2005). The body mass only varied over a small range $(0.53 \mathrm{~kg})$ while body fat had a much wider range $(8.83 \%)$. The heavier muscling of the better players might have contributed to their higher body mass (Fox et al., 1989). In addition, they also had higher body fat. Based on previous studies, the better players would have body fat of 20.92 - 28.90\% (Soh, 2005; Bale \& Hunt, 1986; Withers \& Roberts, 1981).

The good players had a meso-endomorphic somatotype vs. endo-mesomorphic somatotype by the lesser players. Their somatotype was, in fact, the same as that of Malaysian national players. Since it is likely that the good MSSM players today would be the national players of tomorrow, it is to be expected that they have the same somatotype as the national players. However, the lesser players were more mosomorphic, possibly due in part to their lower body fat. Although different somatotypes occurred with the playing performance, the main two ones were mesomorphic and endomorphic.

\section{Conclusion}

The good Malaysian School Sports Council (MSSM) netball players were the tallest, heaviest and had the highest body fat. They had the same characteristics as Malaysian national players who represent the local epitome in playing performance. Their range in body fat was larger than their range in body mass. Although, their body fat was low, it was within the 12-16\% suggested for players in contact sports (Wilmore \& Costill, 1994). The good Malaysian School Sports Council (MSSM) players had the same somototype (meso-endomorphic) as more elite/senior teams. The lesser players had an endomesormorphic somatotype.

\section{References}

Adams, G. M. (1994). Exercise physiology: Laboratory manual $\left(2^{\text {nd }}\right.$ ed.). Dubuque: Brown and Benchmarkr.

Bale, P., \& Hunt, S. (1986). The physique, body composition and training variables of elite and good netball players in relation to playing position. The Australian Journal of Science and Medicine in Sport, 18(4), 16-19.

Fox, E. L., Bowers, R. W., \& Foss, M. L. (1993). The physiological basis for exercise and sport (5th ed.). Dubuque: Brown and Benchmark.

Hopper, D. M. (1997). Somatotype in high performance female netball players may influence player position and the incidence of lower limb and back injuries. British Journal Sport Medicine, 31, 197-199.

Hopper, D. M., Hopper, J. L., \& Elliot, B. C. (1995). Do selected kinanthropometry and performance variables predict injuries in female netball players? Sports Sciences, 13, 213-222.

Jackson, A. S., Pollock, M. L., \& Ward, A. (1980). Generalized equations for predicting body density of women. Medicine and Science in Sports and Exercise, 12(12-17).

Lohman, T. G., Roche, A. F., \& Martorell, R. (1991). Anthropometric standardization reference manual (Abridged ed.). Champaign, IL: Human Kinetics. 
Marfell-Jones, M., Olds, T., Stewart, A., \& Carter, L. (2006). International standards for anthropometric assessment ISAK. Potchefstroom, South Africa.

Nie, N. H., Hull, C. H., Jenkins, J. G., Steinbrenner, K., \& Bent, D. H. (1975). SPSS statistical package for the social sciences (2nd ed.). New York: McGrawHill Book Company.

Pallant, S. (2001). SPSS survival manual : A step by step guide to data analysis using SPSS (version 10). Illinois: Allen and Unwin.

Soh, K. G. (2005). Anthropometric profile of top Malaysian netball players. African Journal for Physical, Health Education, Recreation and Dance, 11(4), 464-471.

Soh, K. G., Ruby, H., \& Soh, K. L. (2006). Body fat comparison among Malaysian netball and basketball players. Journal of University Malaya Medical Centre, 9 (1), 2006, 20-22.

Soh, K. G., Ruby, H., \& Soh, K. L. (2007). Physical Characteristics of Malaysian Netball Players in Relation to Playing Skill. Journal of Physical Education \& Recreation (Hong Kong). 13 (1). 5457.
Telford, R., Barnes, J., Tumilty, D., \& Hahn, A. G. (1985). Body fat measures in athletes with a special reference to female basketballers and netballers. Sports Coach, 9(1), 32-37.

Tothill, P., \& Stewart, A. (2002). Estimation of thigh muscle and adipose tissue volume using magnetic resonance imaging and anthropometry. Journal of Sport Sciences, 20(7), 563-576.

Wilmore, J. H., \& Costill, D. L. (1994). Physiology of sports and exercise. Champaign, IL: Human Kinetics Publisher.

Withers, R. T., \& Roberts, R. G. D. (1981). Physiological profiles of representative women softball, hockey and netball players. Ergonomics, 24(8), 583-591.

\section{Correspondence:}

Dr. Soh Kim Geok

Associate Profesor

Sports Studies Department,

Faculty of Educational Studies,

University Putra Malaysia, MALAYSIA.

E-mail : kim@educ.upm.edu.my or kimgeoks@yahoo.com

Tel : 603-89468153 (Office) or 6019-3649715 (Mobile)

Fax : 603-89435386 